\title{
Are Governors Responsible for the State Economy? Partisanship, Blame, and Divided Federalism
}

\author{
Adam R. Brown \\ Assistant Professor \\ Dept of Political Science \\ Brigham Young University \\ 745 SWKT \\ Provo, UT 84602 \\ (801) 422-2182 \\ brown@byu.edu
}

Forthcoming in the Journal of Politics. Copyright Southern Political Science Association.

I thank Gary Jacobson, Craig Burnett, Matt Childers, John Geer, Navin Kartik, Sam Kernell, Thad Kousser, Keith Poole, Michael Schudson, members of the Brigham Young University political science department, and participants at the 8th annual State Policy and Politics Conference for their comments on various drafts of this article. Faults remain my own 


\begin{abstract}
In the United States, voters directly elect dozens of politicians: Presidents, governors, legislators, mayors, and so on. How do voters decide which politician to blame for which policy outcomes? Previous research on gubernatorial approval has suggested that voters divide policy blame between governors and the president based on each office's "functional responsibilities"-requiring that responsibilities are clearcut, which is seldom true. Using data from four surveys, I show that voters actually divide responsibility for economic conditions in a partisan manner, preferring to blame officials from the opposing party when problems arise.
\end{abstract}

Keywords: gubernatorial approval, partisanship, blame, federalism, state politics 
The United States is unique among democracies in the burden it imposes on its voters. Not only are American elections frequent, but they feature a dizzying number of choices. In California, often an extreme example of this tendency, each voter in 2006 had to evaluate thirteen proposed initiatives in addition to candidates for seven statewide offices, two Congressional offices, two state legislative offices, and various judgeships. As if that were not enough, most voters would also have found on their ballots candidates for their city council, county board of supervisors, school board, and other (often obscure) local elected offices.

The difficulties created by such a complex hyper-democratic system have given rise to entire literatures dealing with voter fatigue, ballot rolloff, and voter sophistication. However, the presence of so many independently-elected officials, often with overlapping responsibilities, creates an additional problem: Blame. Elections are thought to provide a link whereby voters can hold elected officials responsible for their activities in office (Ferejohn 1986). But when something goes wrong-unemployment is high, schools are failing, or crime is up-how do voters know which of all these politicians to hold responsible?

To examine all the diverse and complicated layers of authority in America's federal system would be beyond the scope of this paper. Instead, I pay primary attention to the most prominent politician at each level of American federalism: Presidents and governors. I am by no means the first to explore this relationship; indeed, several well-regarded publications have debated how state and national conditions interact in gubernatorial elections. The reigning argument at present is that voters evaluate governors and presidents with reference to each office's "functional responsibilities," expecting presidents to provide national security and Social Security while expecting governors to provide education, highways, and prosperity (Atkeson and Partin 1995, 2001; Arceneaux 2006). 
However, this sort of argument fails to account for the powerful and well-documented role that partisanship plays in structuring American voters' behavior. My argument, detailed below, is that Americans rely heavily on partisan shortcuts when deciding whether to hold their governor (as opposed to the president) responsible for state-level policy outcomes-especially when functional responsibility for a particular policy area is shared by both the governor and the president. Of course, it's far from novel to suggest that partisanship matters in American politics; previous research has shown abundantly that voters tend to have more patience with politicians of their own party than with politicians from the other side. My major claim is not just that partisanship matters, then, but rather that partisanship helps determine which policy results get attributed to the governor and which get attributed to the president. Previous work on gubernatorial elections has erred by emphasizing functional responsibility without also taking account of partisanship.

To be clear, I do not intend to argue that voters will completely ignore the president's and governor's actual functional responsibilities; even the least engaged citizen should know that governors have as little control over foreign policy as presidents have over potholes. Rather, my argument is that partisan considerations will influence allocations of blame in the many policy areas where the president and the governor share responsibility_an argument I test by analyzing responsibility for the state's economy. When the president and the governor belong to the same party, there is not much opportunity for a partisan blame game to develop between them. But when they belong to different parties, a situation I refer to as "divided federalism," partisan voters gain the opportunity to blame one for economic problems while giving the other a free pass. Just as divided government creates a potential blame game between the president and Congress, divided federalism creates a similar situation between the president and the governors. 
I proceed now by briefly reviewing the two main literatures I draw on-the literatures on partisan bias and on gubernatorial elections-and show how the latter can benefit by incorporating insights from the former. I then explore three specific empirical implications of this theoretical argument.

\section{A Theory of Partisan Bias and Divided Federalism}

Studies of partisan bias began decades ago with the psychological model introduced in The American Voter (Campbell et al. 1960); an updated take on this argument is that voters simply reject information that challenges their prior beliefs (Zaller 1992), or that they choose to give greater credibility to information from sources they trust (Lupia and McCubbins 1998; Page, Shapiro, and Dempsey 1987), even if those sources are potentially biased.

Regardless of which of these mechanisms produces partisan bias, we have evidence that the biases exist. First, we have evidence that partisanship colors voter evaluations of policy outcomes: Conover, Feldman, and Knight have provided detailed evidence that retrospective (1986) and prospective (1987) economic evaluations strongly reflect respondents' political views, arguing that these evaluations "become extensions of partisan evaluations of the president's capabilities" (1987, 578; see also Bartels 2002). A similar story arises with regard to consumer confidence surveys; although actual economic conditions have a strong impact on consumer confidence, political evaluations also play a significant role (DeBoef and Kellstedt 2004). In addition, we have evidence that partisan factors influence whether voters will consider economic conditions when voting in Congressional elections (Fiorina 1983; Hibbing and Alford 1981).

These findings have come from research primarily concerned with the national setting; these insights have not been fully applied to the subnational context. In fact, the second literature 
I draw on-the literature on gubernatorial approval and elections-has largely overlooked these results. Instead, most research in this second literature has debated whether voters hold governors accountable for local (i.e. state-level) conditions or whether governors are entirely at the mercy of the president's coattails. Few dispute that national partisan trends and national economic conditions influence gubernatorial approval and elections; the question has been whether local conditions, typically operationalized with state economic indicators, also matter.

The answer to this latter question has remained elusive. Table 1 summarizes the results of several influential studies; the inconsistency is striking. Some studies have found that state economic variables affect gubernatorial approval (Atkeson and Partin 1995; Jacobson 2006; Niemi et al. 1995); others have found that they do not (Crew and Weiher 1996; Peltzman 1987); and still others have found the effect to be contingent on some other factor (Ebeid and Rodden 2006; Leyden and Borrelli 1995; Stein 1990). These inconsistencies may arise from a widespread but implicit assumption that if local conditions matter, all voters will objectively take equal account (or non-account) of them when evaluating the governor-an assumption at serious odds with the work on partisanship and bias referenced above.

\section{[Table 1 about here]}

Those arguing that only national conditions affect gubernatorial popularity imply, in effect, that voters blame the president for every policy outcome, at any level, and evaluate all subnational politicians based solely on the president's performance. ${ }^{1}$ Those arguing that local conditions also matter imply that voters have some standard by which to assign responsibility for some policies to the governor even while assigning responsibility for other policies to the president. As noted earlier, the major argument at present is that voters assign blame based on the president's and governor's actual responsibilities: Voters perceive objective differences 
between the duties of presidents and governors and vote accordingly. This explanation omits partisan bias entirely, predicting instead that all voters will attribute responsibility for the same issues to the same officials.

My argument modifies this functional responsibility hypothesis by introducing insights from the literature on partisanship and bias. I do not attempt to displace the functional responsibility claims entirely; when gubernatorial and presidential responsibilities are clearly delineated, we may well observe voter behaviors roughly consistent with the functional responsibility argument. But when responsibilities are unclear, as is often the case, the functional responsibility mechanism cannot logically operate. In this situation, I expect the literature on partisanship and bias to become relevant. Rudolph (2003) has already shown that partisan considerations affect whether a voter will blame Congress or the president for national economic problems. My central claim is that American federalism creates a similar blame game between governors and the president: Voters will tend to blame whichever level of government that is not controlled by their own party.

Recently, Malhotra and Kuo (2008) published the results of an experimental survey that illustrates my argument. In their poll, they asked respondents to attribute blame among federal, state, and local officials for the government's poor response to Hurricane Katrina. Respondents were randomly assigned to receive different information about these officials. When provided with information about each official's responsibilities, voters tended to assign blame in a manner consistent with the functional responsibility hypothesis. But when provided only with each official's partisan affiliation, respondents tended to blame officials from the opposite party. These experimental results reinforce my claim that voters will rely on partisan shortcuts when functional responsibilities are unclear. 
I confirm and expand these experimental findings by examining real-world data in another policy area where functional responsibilities are particularly murky: Economics. Even the functional responsibility theorists disagree as to whether governors or presidents bear responsibility for economic conditions, illustrating just how imprecise the division of labor is. ${ }^{2}$ Because functional responsibility for the economy is ambiguous, I expect voters to assign blame in a partisan manner-but only when the governor and president belong to different parties. In the absence of this divided federalism, voter partisanship should not make much difference. Stated precisely: When the governor and the president belong to different parties, voter partisanship should strongly influence whether voters will blame the governor instead of the president for a particular policy outcome.

I test this general argument by exploring three of its observable implications. First, I begin with a reanalysis of Stein's (1990) study of the 1982 gubernatorial elections, in which voters were asked explicitly to assign blame for state economic problems to either the president or their governor. As it happens, voters do indeed assign blame in a more partisan manner under divided federalism. Second, I use recent polling data to show that partisan considerations also influence whether respondents think their state's economy is outperforming the nation's; under divided federalism, voters overestimate the economic performance of whichever level of government that their party controls. Third and most importantly, I address the major question of the gubernatorial elections literature-namely, whether voters hold governors accountable for state-level economic conditions. The widely-used functional responsibility argument implies that all voters should do so. By contrast, I find that partisan biases determine whether state economics correlate with gubernatorial approval—a pattern that may explain the mixed findings summarized in Table 1. 


\section{Partisanship and Blame}

Stein (1990) was the first to recognize that voters might disagree as to whether the president or governor bore responsibility for the state's economy. Nevertheless, he did not seek to explain this heterogeneity, choosing instead to treat blame as exogenous. By revisiting the 1982 exit poll data that he used, however, we can see clear evidence that partisanship strongly influences attributions of blame. Table 2 replicates one of Stein's tables, summarizing how voters in each state chose to assign blame for the state's economy. Only in California, New York, and Nevada did more respondents blame their governor than blamed Ronald Reagan.

[Table 2 about here]

By contrast, Table 3 presents the same data divided by partisan subgroup, an analytic step Stein did not take. This simple change makes it apparent that blame strongly reflects respondent partisanship. In every state with a Democratic governor, Republicans blamed their governors and Democrats blamed Reagan, a Republican; in every state with a Republican governor, Republicans blamed neither Reagan nor the governor, and Democrats blamed Reagan or (more frequently) both. And across the board, Republicans were more likely to claim that neither Reagan nor the governor was to blame, or perhaps that there were no problems to blame on anybody - a pattern that may reflect some weaknesses with the survey question. ${ }^{3}$

\section{[Table 3 about here]}

Once we take account of respondent partisanship in this manner, respondents with Democratic governors showed broad consensus in their decisions about blame; Democrats blamed Reagan alone by a 40.3 point margin, while Republicans blamed the governor alone by a 20.3 point margin, which combine for a net partisan effect of 60.6 percentage points. Meanwhile, respondents with Republican governors showed far less agreement. Democrats continued to 
favor blaming Reagan, but by only half the margin (23.9 points); by contrast, Republicans were torn between blaming Reagan and the governor, blaming governors by an inconsequential 1.3 point margin. To quantify the effect of partisanship on attributions of blame, note that the difference in differences is 60.6 points in states with Democratic governors but only 25.3 points in states with Republican governors; respondent partisanship had a much weaker effect in the latter set of states than in the former.

It appears, then, that respondent partisanship shaped attributions of blame in 1982; in turn, Stein's important work shows that these attributions determined whether economic conditions affected governors on election day. These partisan patterns were most obvious under divided federalism, since respondents could choose to blame either the Democratic governor or the Republican president. Without divided federalism, the patterns were far weaker; with both the governor and the president belonging to the same party, respondents were less sure whether to blame both or neither. Respondent partisanship mattered much more under divided federalism than elsewhere in determining allocations of blame.

\section{Partisanship and Economic Evaluations}

The 2006 gubernatorial elections took place in a similar context as the 1982 elections: The economy was generally weak, and the president was a Republican. This similarity affords us the methodologically important opportunity to test whether patterns observed in one context (the 1982 elections) also occurred in another (the 2006 elections). Although pollsters in 2006 did not ask an explicit blame question like they did in 1982, though, they did ask questions that ought to reflect other observable implications of my theoretical argument. In particular, respondents to the Cooperative Congressional Election Study (CCES) were asked to evaluate their state's and the nation's economies. ${ }^{4}$ As discussed earlier, previous research has shown that presidential approval 
strongly influences evaluations of the national economy. As a straightforward extension of this insight, under divided federalism we should expect economic evaluations to favor whichever level of government that is controlled by a respondent's preferred party.

To address this question requires survey data in which respondents evaluate their state's economy relative to their nation's - not their state economy alone. Under divided federalism, we should observe strong partisan biases; members of the governor's party should overestimate the state economy's health relative to the nation's, while members of the president's party should do the opposite. Without divided federalism, we should not observe this pattern; all respondents should be equally likely to over- or underestimate the state's health relative to the nation's.

Unfortunately, pollsters do not typically ask for such relative evaluations of the state economy as compared to the nation's. Nevertheless, we can easily construct such a relative measure from the CCES data. Respondents evaluated their state's economic health over the previous year; they answered a similar question about the national economy. Both questions used a closed-form response ranging over a five-point scale from "much better" and "better" to "worse" and "much worse." By subtracting national evaluations from state evaluations, we can construct an index measure of each respondent's evaluation of the state's economy relative to the nation's. This new measure ranges from -4 (the state economy is much worse than the national economy) to +4 , though scores fall between -2 and +2 (inclusive) for $97 \%$ of respondents. ${ }^{5}$ This variable is almost perfectly normal, with mean -0.07 and standard deviation 1.03 , indicating that respondents do not systematically favor one level of the economy over the other.

An advantage of this composite measure is that it has a correct answer that respondents should have given, regardless of personal political beliefs: Either the state economy was stronger than the national economy or it was not. In a world of objective, informed citizens, raw 
economic indicators would predict most (or all) of the variance in this measure. Such objectivity seems to be assumed in three of the most widely read studies dealing with gubernatorial approval—that is, Atkeson and Partin (1995), Carsey and Wright (1998), and Stein (1990). In these three studies, the authors attempt to learn whether governors are held accountable for statelevel economic conditions; in all three studies, the authors measure state economic conditions using respondent evaluations of the state economy rather than using raw macroeconomic indicators. This method is not problematic as long as respondent evaluations actually measure the true pulse of the state's economy-a proposition that the theoretical arguments presented above should lead us to question. By contrast, if partisan biases influence respondent economic evaluations, then regressing gubernatorial approval on economic evaluations as these three studies do might not be much different from regressing gubernatorial approval on itself.

Table 4 presents the results of two linear regressions that test these ideas. In each, the dependent variable is the respondent's evaluation of the state's economy relative to the nation's, as discussed above. The first independent variable is each state's average May-November 2006 unemployment rate, with the national rate subtracted out, interacted with respondent partisanship. Regardless of the governor's partisanship, the state's unemployment rate does have a modest relationship with economic evaluations; states with a higher relative unemployment rate receive lower relative evaluations. Respondent partisanship also matters; in both regressions, Democrats tended to give higher ratings to their state relative to the nation than Republicans did, likely as a result of Bush's polarizing stewardship of the national economy.

[Table 4 about here]

Most significantly, though, the relationship between state unemployment and respondent partisanship is strongly interactive-but only under divided government (that is, where the 
governor was a Democrat in 2006). The marginal effect for Democrats with Democratic governors is statistically similar to the marginal effect for respondents of either party with Republican governors; all three estimated coefficients fall between 0.10 and 0.17 . For these three types of respondent, actual economic conditions clearly had a meaningful effect on their economic evaluations, but not an overwhelming one; a one-point rise in a state's unemployment rate relative to the nation's would produce only a modest (0.10-0.17) drop in respondents' evaluations of the state's economy relative to the nation's. ${ }^{6}$ For Republicans with Democratic governors, however, the estimated effect is two to three times stronger at -0.38 .

This interactive finding does not imply that Republicans are necessarily more objective than Democrats; if that were the case, the interaction would not be limited to states with divided federalism. Rather, it shows that partisanship and federalism interact to influence how respondents assign blame for policy problems in their states. Republicans with Democratic governors had every reason to blame their governor for high unemployment in 2006; the alternative was blaming their Republican president. By contrast, Democrats with Democratic governors had an opportunity to shift some of the responsibility for their state's economic conditions to the president, resulting in a decreased coefficient for this group.

More broadly, the general finding in this table is that respondent partisanship produces stronger perceptual biases under divided federalism than elsewhere. Where the governor and the president belonged to different parties, partisanship had a strong effect on respondent evaluations of the state's economy relative to the nation's; where the governor and the president belonged to the same party, partisanship had almost no effect. ${ }^{7}$ These patterns are consistent with those reported in the previous section. 


\section{Gubernatorial Approval and Economic Conditions}

I now turn to the gubernatorial approval literature's major debate: Whether voters hold governors responsible for state-level economic conditions. As summarized in Table 1 earlier, previous research has been unable to show conclusively whether state economic conditions influence gubernatorial popularity. The results thus far suggest a possible reason for the literature's mixed results. First, I have shown that voters assign responsibility for the state economy in a partisan manner-particularly under divided federalism. Second, I have shown that voters form perceptions of the state's economy relative to the nation's in a partisan mannerparticularly under divided federalism. Together, these results imply that the statistical relationship between state economic conditions and gubernatorial approval will be mediated by voter partisanship_-particularly under divided federalism.

The 2006 CCES survey included questions about gubernatorial approval, making a test of this claim possible. CCES respondents appraised their respective governors along a four-point scale, from "strongly disapprove" and "disapprove" to "approve" and "strongly approve." 8 Although many variables may affect approval, the focus here is on the governor's responsibility for the state's macroeconomic health-in particular, its unemployment rate, a variable worth investigating because it has produced such inconsistent results in previous research. ${ }^{9}$

Table 5 presents the results of four regressions. The first two use ordered logit; the next two estimate the same models using ordinary least squares. In each pair, the first model covers states with divided federalism (i.e. Democratic governors in 2006) and the next covers the remaining states. The dependent variable is the respondent's evaluation of the governor. Strictly speaking, ordered logit would be the most appropriate tool for predicting this ordinal fourcategory variable. However, OLS gives substantively similar results; because it is easier to 
interpret, I will restrict my discussion below to the two OLS models. The most important variable is each state's unemployment rate, interacted with partisanship. ${ }^{10}$ As predicted, the effect of state economic performance is not constant across partisan subgroups. Under divided federalism, there is a strong, statistically significant partisan interaction; the state's unemployment rate had a clear effect on gubernatorial approval among Republican respondents but no measurable effect among Democratic respondents. Without divided federalism, by contrast, Republican and Democratic respondents were statistically indistinguishable.

[Table 5 about here]

Table 6 replicates the preceding analysis using gubernatorial approval data gathered at a different point in time (early 2006) by a different organization (SurveyUSA). ${ }^{11}$ The independent variables are state unemployment rates and state-level approval ratings for George W. Bush among the specified partisan subgroup. The approval and unemployment measures are averages covering January through March 2006. ${ }^{12}$ New Jersey and Virginia are omitted, since they held gubernatorial elections in November 2005 and their new governors were only beginning their terms during this period.

\section{[Table 6 about here]}

The estimated effects of state unemployment rates on gubernatorial approval are the coefficients of greatest theoretical interest. Again, partisan differences are strong under divided federalism but weak and insignificant elsewhere. Because SurveyUSA releases only aggregate approval data, I cannot run the same interactive models as in Table 5, nor can I include the same demographic controls. Nevertheless, the partisan differences are apparent. As in Table 5, where the governor was a Democrat, Republicans held their governors accountable for high unemployment but Democrats did not; elsewhere, there was not a significant partisan pattern. 
We can observe the same pattern yet again in a replication of Carsey and Wright's (1998) model of the effects of state economic evaluations on gubernatorial voting. The first column in Table 7 reprints their final logit estimates of the effect of respondent evaluations of the state economy on the probability of voting for the incumbent gubernatorial candidate. Although their analysis (and my replication) contains several additional variables, I display only one coefficient from each logit model-the estimated marginal effect of respondent economic evaluations. When I estimate these regressions separately by respondent party in the latter two columns of the table, the importance of divided federalism again becomes apparent. Table 7 tells the same story as Tables 5 and 6: In states with divided federalism, the estimated effect of state economic conditions on gubernatorial voting was more than three times as strong among the president's copartisans as among the governor's. In states without divided federalism, there was no meaningful partisan difference.

\section{[Table 7 about here]}

This interactive finding in Tables 5, 6, and 7 might seem odd if not for the other results discussed earlier in this paper. Recall that under divided federalism, respondents can choose to blame either their governor or the president for high unemployment. As Table 3 shows, members of the president's party living under divided federalism are the group that is most likely to choose to blame the governor for state-level economic problems. And as Table 4 shows, this is the same group of respondents that is likely to sharply adjust its state economic evaluations downward when confronted with poor economic performance. In light of these two earlier findings, it is hardly surprising that this same group of respondents also takes strongest account of poor economic conditions when evaluating their governors. 


\section{Discussion}

The preceding analysis leads to three major conclusions. First, partisanship has a strong influence on how voters assign responsibility for policy outcomes. When functional responsibilities are shared among officials from opposing parties, voters assign blame in a partisan manner; they do not assign blame objectively based only on each official's job description. Second, partisanship also influences how voters perceive policy performance by various levels of government. When the president and the governor belong to opposing parties, voters will overestimate the policy success of whichever level of government that is controlled by their preferred party. And third, partisanship influences whether voters will hold the governor accountable for the state economy. The effect of state economics on gubernatorial approval varies among partisan subgroups-but only when the president and the governor belong to different parties. This latter conclusion follows logically from the first two.

For several years, researchers have struggled to show whether voters hold governors accountable for national or state-level conditions. This question certainly merits attention; if governors—-the most prominent elected officials after the president—are evaluated largely on the basis of national partisan trends, then we ought to seriously reconsider the nature and value of subnational elections. Despite the importance of this question, however, previous research has produced inconsistent results. The preceding analysis suggests a reason why: The existing literature on gubernatorial approval has failed to appreciate the importance of respondent partisanship in mediating the relationship between policy performance and gubernatorial approval. The "functional responsibility" theory that motivates much of the work on gubernatorial approval assumes that all voters will act the same, regardless of party-an assumption at odds with long-established findings in the literature on partisanship and bias. 
Of course, I would not go so far as to claim that every existing analysis would have found a significant relationship between state economic conditions and gubernatorial approval if only it had fully accounted for partisanship and divided federalism; after all, idiosyncratic features of a particular state or year may temporarily reduce the salience to voters of the state's economy (cf. Zaller 1992). That being said, scholarly inattention to partisanship and divided federalism may well explain some of the literature's inconsistency. The prevalence of divided federalism has varied widely over the past fifty years, fluctuating from a high of 74 percent of states to a low of 26 percent of states being governed by the president's party. Suppose that, because of these yearto-year variations, a particular study happened to disproportionately sample states with divided federalism. If most respondents in those states belonged to the president's party, then the analysis would be more likely to find a relationship between economics and approval; if not, then the opposite would be true.

The only way to know for sure whether such was actually the case would be to replicate every existing study. For practical reasons, I have not done so. Nevertheless, I derive some confidence in the robustness of my findings from the diversity of data sources examined in this analysis. In various parts of this paper I have used the 1982 CBS/New York Times exit polls, the 1986 CBS/New York Times exit polls, the 2006 Cooperative Congressional Election Study, and 2006 gubernatorial approval data from SurveyUSA; in every case, the data produced results consistent with my theory. Along the way, I have replicated portions of two widely read studies—Stein's (1990) and Carsey and Wright's (1998)—and found results consistent with my theory.

Federalism plays a central role in American voting behavior. Subnational elections are not held in a vacuum, but rather in the context of national political conditions. However, this 
analysis demonstrates that federalism's role differs somewhat from what researchers have previously thought. Recent research has argued that voters hold state and federal officials accountable for different sets of issues; in this line of thinking, voters recognize that state and federal officials have differing policy responsibilities and judge them accordingly. Such an argument presupposes that the lines dividing federal from state authority are clear. Although state and federal powers may have been neatly divided at America's founding, the divisions are now extremely blurred-especially in the realm of economic policy.

My findings do not necessarily refute the functional responsibility argument entirely; the functional responsibility hypothesis may explain voter behavior in issue areas where responsibilities are more clear-cut, as implied by Malhotra and Kuo's findings (2008). But at least in issue areas where responsibility is uncertain, such as economic policy, voters rely instead on partisan cues when assigning blame for policy outcomes. Presidential, gubernatorial, and respondent partisanship interact to determine how voters assess gubernatorial performance. When it suits their partisan predispositions, voters blame their governor for state-level problems; when it does not, they do not.

In addition, this partisan logic also affects voter judgments of policy outcomes. Partisan biases have clear, meaningful effects on respondent evaluations of the state's economic health. A handful of well-regarded studies have used correlations between retrospective economic evaluations and gubernatorial approval to argue that voters do, in fact, hold governors responsible for the state's economy (Atkeson and Partin 1995, 1998; Carsey and Wright 1998; Stein 1990). But given that retrospective evaluations are strongly influenced by respondent partisanship, political scientists should hesitate to use retrospective economic evaluations as indicators of actual economic performance. 


\section{Notes}

${ }^{1}$ This may read as a straw man, but it is frequently implied in the gubernatorial elections literature. Peltzman's words provide one example: "[Americans] vote as if they understand that national rather than local policies have the dominant effect on their income" $(1987,296)$.

${ }^{2}$ Atkeson and Partin (1995) assign all economic responsibility to governors; Carsey and Wright (1998) argue that presidents bear national economic responsibility while governors are responsible only for the state's economic health relative to the nation's.

${ }^{3}$ The poll asked, “Who's more to blame for economic problems in (respondent's state): President Reagan, Governor (name), both, or neither?" Perhaps some who said "neither" thought there were no economic problems — or at least, they did not want to admit that Republican leaders had failed them. Or perhaps they thought that economic problems arose independently of government policies. The latter explanation would be consistent with Rudolph's (2003) work, which shows that economically conservative respondents will blame labor or business leaders for economic conditions, given the opportunity to do so, regardless of partisan considerationsalthough economic conservatism does tend to correlate with Republicanism.

${ }^{4}$ Polimetrix fielded the CCES during the November 2006 elections under the direction of Stephen Ansolabehere, Doug Rivers, and Lynn Vavreck. This survey involved over 30,000 respondents answering questions on dozens of topics. For details, see http://web.mit.edu/polisci/portl/cces/.

${ }^{5}$ Because respondents have only five options when evaluating either the state or national economy, it is possible that an extremely optimistic respondent could give the highest score to the nation but find herself unable to give an even higher score to the state. To verify that this potentiality did not skew any of the results below, I repeated all these analyses omitting the 4,474 
respondents who gave the best (or worst) possible evaluation both to their state and to the nation; the substantive conclusions were the same.

${ }^{6}$ Unemployment rates have a st. dev. of 1.04; these economic evaluations have a st. dev. of 1.03. As such, these marginal coefficients are roughly equivalent to standardized coefficients.

${ }^{7}$ Note that this does not mean that there are no partisan biases in states governed by the president's party, only that there is no bias toward (or against) the state as opposed to the nation.

${ }^{8}$ Respondents choosing the "not sure" option are omitted from this analysis, since "not sure" can mean either "I don't know" or "neutral." The variable is coded from 1 through 4.

${ }^{9}$ Careful readers might object to my use of unemployment by reference to the "issue ownership" literature, pointing out that Democrats own the issue of unemployment (Petrocik 1992).

Nevertheless, the nature of my findings suggests that more than issue ownership is at work. Issue ownership would lead us to expect Democratic governors (not Republican governors) to be held accountable for unemployment, regardless of presidential party; we might also expect Democratic respondents to care more than Republican respondents about unemployment. Together, these expectations would lead us to predict patterns very different from those I find. ${ }^{10}$ State unemployment rates are averaged over the six months preceding the survey. Demographic control variables include respondent income and dummies for race, marriage, sex, education, home ownership, and employment status. Louisiana is omitted because of its political and economic volatility following Hurricane Katrina

${ }^{11}$ Approval ratings are measured only among those expressing an opinion. Louisiana is again omitted. Brown (2008) and Jacobson (2006) discuss SurveyUSA's reliability and validity. 12 This decision was arbitrary but not consequential; when using data from other periods in the SurveyUSA series, the results are essentially the same. See Brown (2008). 


\section{References}

Arceneaux, Kevin. 2006. "The Federal Face of Voting: Are Elected Officials Held Accountable for the Functions Relevant to Their Office?" Political Psychology 27 (5), 731-754.

Atkeson, Lonna Rae, and Randall W. Partin. 1995. "Economic and Referendum Voting: A Comparison of Gubernatorial and Senatorial Elections." American Political Science Review 89 (March): 99-107.

Atkeson, Lonna Rae, and Randall W. Partin. 2001. "Candidate Advertisements, Media Coverage, and Citizen Attitudes: Agendas and Roles of Senators and Governors." Political Research Quarterly 54 (December): 795-813.

Bartels, Larry M. 2002. "Beyond the Running Tally: Partisan Bias in Political Perceptions." Political Behavior 24 (2): 117-50.

Brown, Adam R. 2008. "Strategic Politicians in Gubernatorial Elections." Ph.D diss. University of California, San Diego.

Campbell, Angus, Philip Converse, Warren Miller, and Donald Stokes. 1960. The American Voter. New York: John Wiley \& Sons, Inc.

Carsey, Thomas M., and Gerald C. Wright. 1998. "State and National Factors in Gubernatorial and Senate Elections.” American Journal of Political Science 42 (July): 994-1002.

Chubb, John E. 1988. "Institutions, the Economy, and the Dynamics of State Elections." American Political Science Review 82 (March): 133-154.

Conover, Pamela Johnston, Stanley Feldman, and Kathleen Knight. 1987. "The Personal and Political Underpinnings of Economic Forecasts." American Journal of Political Science 31 (3): 559-83.

Conover, Pamela Johnston, Stanley Feldman, and Kathleen Knight. 1986. "Judging Inflation and 
Unemployment: The Origins of Retrospective Evaluations." Journal of Politics 48 (3):565-88.

Crew, Robert E. Jr., and Gregory R. Weiher. 1996. “Gubernatorial Popularity in Three States: A Preliminary Model.” Social Science Journal 33 (1): 39-54.

De Boef, Suzanna, and Paul M. Kellstedt. 2004. "The Political (and Economic) Origins of Consumer Confidence." American Journal of Political Science 48 (October):633-649.

Ebeid, Michael, and Jonathan Rodden. 2006. "Economic Geography and Economic Voting: Evidence from the US States." British Journal of Political Science 36: 527-547.

Ferejohn, John. 1986. "Incumbent Performance and Electoral Control." Public Choice 30 (fall): $5-25$.

Fiorina, Morris P. 1983. "Who Is Held Responsible? Further Evidence on the Hibbing-Alford Thesis." American Journal of Political Science 27 (February): 158-164.

Hibbing, John R., and John R. Alford. 1981. "The Electoral Impact of Economic Conditions: Who Is Held Responsible?" American Journal of Political Science 25: 423-39.

Jacobson, Gary C. 2006. "Polarized Opinion in the States: Partisan Differences in Approval Ratings of Governors, Senators, and George W. Bush." Paper prepared for delivery at the Annual Meeting of the Midwest Political Science Association, Chicago, Illinois, April 20-23.

Kenney, Patrick J. 1983. "The Effects of State Economic Conditions on the Vote for Governor." Social Science Quarterly 64 (March): 154-161.

Leyden, Kevin, and Stephen Borrelli. 1995. "The Effect of State Economic Conditions on Gubernatorial Elections: Does Unified Government Make a Difference?" Political Research Quarterly 48 (June): 275-290. 
Lupia, Arthur, and Mathew McCubbins. 1998. The Democratic Dilemma: Can Citizens Learn What They Need to Know?" Cambridge: Cambridge University Press.

MacDonald, Jason A., and Lee Sigelman. 1999. "Public Assessments of Gubernatorial Performance: A Comparative State Analysis.” American Politics Quarterly 27 (April): 201-215.

Malhotra, Neil, and Alexander G. Kuo. 2008. “Attributing Blame: The Public's Response to Hurricane Katrina.” Journal of Politics 70:120-135.

Niemi, Richard G., Harold W. Stanley, and Ronald J. Vogel. 1995. "State Economies and State Taxes: Do Voters Hold Governors Accountable?” American Journal of Political Science 39 (November): 936-957.

Page, Benjamin, Robert Shapiro, and Glenn Dempsey. 1987. "What Moves Public Opinion?” American Political Science Review 81: 23-44.

Peltzman, Sam. 1987. "Economic Conditions and Gubernatorial Elections.” American Economic Review 77 (2): 293-297.

Petrocik, John R. 1996. "Issue Ownership in Presidential Elections, With a 1980 Case Study." American Journal of Political Science 40 (August): 825-850.

Rudolph, Thomas. 2003. “Who’s Responsible for the Economy? The Formation and Consequences of Responsibility Attributions.” American Journal of Political Science 47:698-713.

Stein, Robert M. 1990. “Economic Voting for Governor and U.S. Senator: The Electoral Consequences of Federalism.” Journal of Politics 52 (February): 29-53.

Zaller, John R. 1992. The Nature and Origins of Mass Opinion. Cambridge: Cambridge University Press. 
Table 1: The Literature's Mixed Findings-Do State Economics Matter?

\begin{tabular}{|c|c|c|c|c|}
\hline \multirow[b]{2}{*}{ Citation and object of study } & \multicolumn{4}{|c|}{ State economic indicators } \\
\hline & Unemployment & Growth & Tax rates & Evaluation \\
\hline \multicolumn{5}{|l|}{ Election Results: Individual Data } \\
\hline $\begin{array}{l}\text { Atkeson and Partin 1995: Cross-sectional } \\
\text { ANES }\end{array}$ & & & & Yes: + \\
\hline $\begin{array}{l}\text { Carsey and Wright 1998: Cross-sectional } \\
\text { ANES, exit polls }\end{array}$ & & & & Yes: + \\
\hline $\begin{array}{l}\text { Niemi et al 1995: Cross-sectional exit } \\
\text { polls }\end{array}$ & & Yes: + & Yes: - & \\
\hline Stein 1990: Cross-sectional exit polls & & & & Contingent $^{\mathrm{a}}$ \\
\hline \multicolumn{5}{|l|}{ Election Results: Aggregate Data } \\
\hline Chubb 1988: 666 gubernatorial elections & & Slight: + & & \\
\hline $\begin{array}{l}\text { Ebeid and Rodden 2006: } 673 \\
\text { gubernatorial elections }\end{array}$ & Contingent & Yes: + & & \\
\hline Kenney 1983: 14-state election series & No & No & & \\
\hline $\begin{array}{l}\text { Leyden and Borrelli 1995: } 215 \\
\text { gubernatorial elections }\end{array}$ & Contingent & & & \\
\hline $\begin{array}{l}\text { Peltzman 1987: } 269 \text { gubernatorial } \\
\text { elections }\end{array}$ & No & No & Yes $^{\text {b }:-~}$ & \\
\hline \multicolumn{5}{|l|}{ Job Approval: Aggregate Data } \\
\hline $\begin{array}{l}\text { Crew and Weiher 1996: Quarterly } \\
\text { surveys, } 3 \text { states }\end{array}$ & No & & & \\
\hline Jacobson 2006: Cross-sectional survey & Yes: - & & & \\
\hline $\begin{array}{l}\text { MacDonald and Sigelman 1999: Cross- } \\
\text { sectional survey }\end{array}$ & & No & Contingent & \\
\hline \multicolumn{5}{|c|}{$\begin{array}{l}\text { Note: "No" means a variable was studied but found to be insignificant. "Yes" means a variable was statistically } \\
\text { significant, affecting incumbents in the indicated direction. If a cell is blank, the given study did not test it. See } \\
\text { text for explanations of contingent effects. } \\
\text { a Stein's respondents evaluate their personal financial situation, not the state economy. } \\
b \text { b }\end{array}$} \\
\hline
\end{tabular}


Table 2: Who is Responsible for the Economic Problems in Your State?

\begin{tabular}{lllll}
\hline \hline State & Reagan & Governor & Both & Neither \\
\hline All states & & & & 34.5 \\
California & 25.4 & 15.4 & 18.4 & 18.3 \\
Connecticut & 28.4 & 36.3 & 17.1 & 39.5 \\
Maine & 32.4 & 15.8 & 12.4 & 36.5 \\
Massachusetts & 37.7 & 13.7 & 12.2 & 40.2 \\
Michigan & 24.3 & 11.3 & 24.3 & 39.9 \\
Minnesota & 20.0 & 14.5 & 25.7 & 40.3 \\
Nebraska & 19.5 & 13.2 & 27.0 & 51.7 \\
Nevada & 16.6 & 9.8 & 21.9 & 46.1 \\
New Mexico & 14.4 & 17.2 & 22.3 & 37.4 \\
New York & 34.0 & 15.6 & 13.1 & 40.3 \\
Ohio & 27.1 & 27.6 & 27.2 & 30.2 \\
Rhode Island & 26.2 & 10.3 & 23.1 & 36.3 \\
Tennessee & 42.4 & 14.0 & 13.4 & 51.5 \\
Texas & 34.5 & 6.8 & 22.5 & 50.8 \\
Vermont & 19.4 & 9.3 & 19.8 & 51.0 \\
Wyoming & 28.4 & 5.7 & 15.0 &
\end{tabular}

Note: Bold type is for emphasis only; see text. Reprinted from Stein (1990, Table 4), based on the 1982 CBS News/New York Times exit polls. 


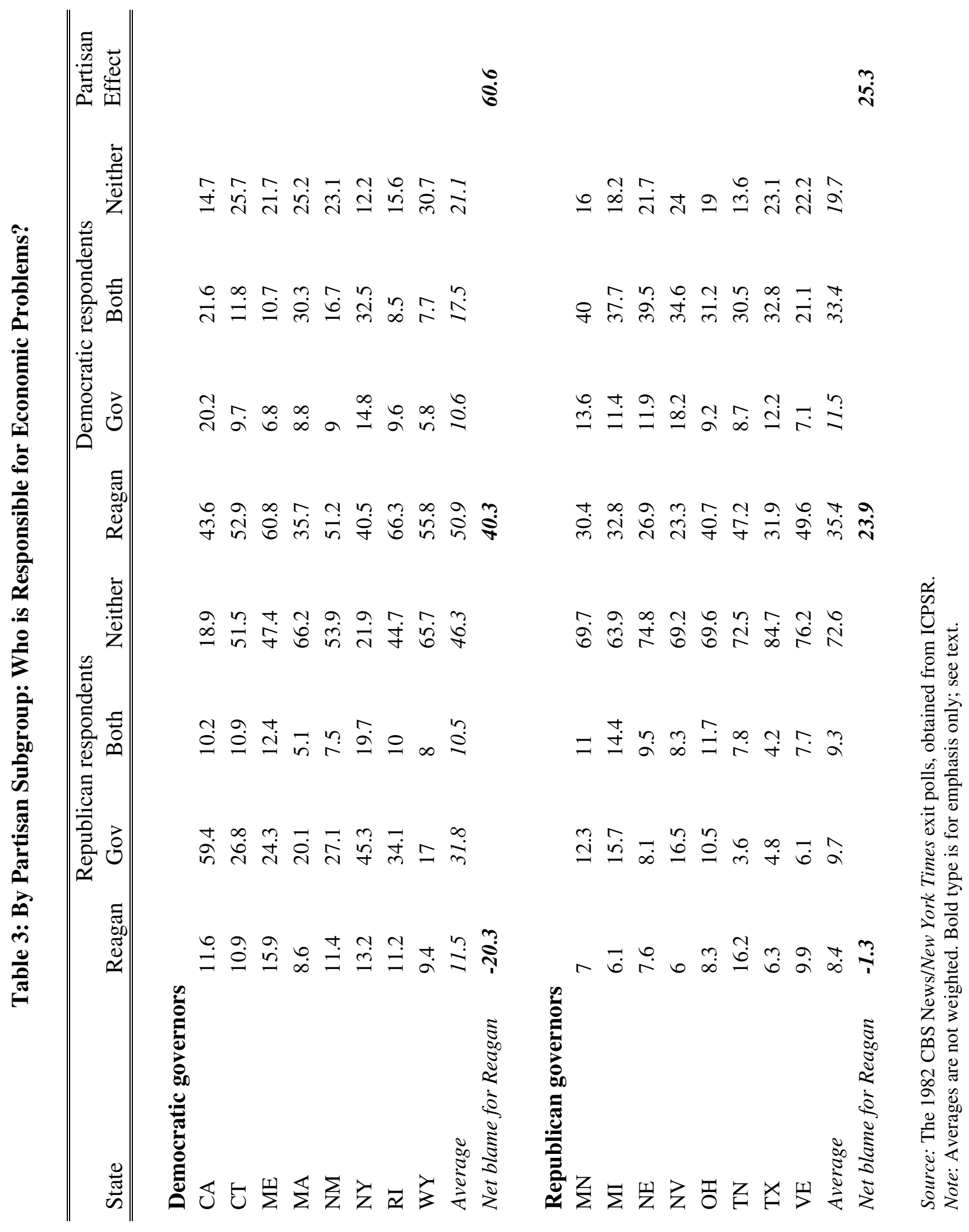


Table 4: Partisan Bias in Evaluating the State's Economy Relative to the Nation's

\begin{tabular}{lll}
\hline \hline & Democratic governor & Republican governor \\
\hline \hline State's unemployment rate relative to nation's & $-0.17^{*}$ & $-0.10^{\dagger}$ \\
& $(0.05)$ & $(0.05)$ \\
* Independent respondent & $-0.09^{*}$ & 0.04 \\
& $(0.02)$ & $(0.03)$ \\
$*$ Republican respondent & $-0.20^{*}$ & 0.00 \\
& $(0.06)$ & $(0.04)$ \\
Independent respondent & $-0.42^{*}$ & $-0.13^{*}$ \\
& $(0.04)$ & $(0.03)$ \\
Republican respondent & $-1.15^{*}$ & $-0.48^{*}$ \\
& $(0.07)$ & $(0.04)$ \\
Demographic controls & Yes & Yes \\
& & \\
Constant & $0.40^{*}$ & $0.26^{*}$ \\
& $(0.09)$ & $(0.04)$ \\
$\mathrm{N}$ & 10,810 & 15,997 \\
Clusters (states) & 22 & 28 \\
$\mathrm{R}^{2}$ & 0.27 & 0.10 \\
Note: The dependent variable is the respondent's evaluation of the state's economy relative to the nation's. \\
Cluster-corrected standard errors in parentheses; sampling weights applied. Demographic controls include income, \\
marital status, race, sex, education, home ownership, and employment status. 'p $\leq 0.10,{ }^{*} \mathrm{p} \leq 0.05$.
\end{tabular}


Table 5: Gubernatorial Approval and the State Economy (CCES)

\begin{tabular}{|c|c|c|c|c|}
\hline \multirow[b]{2}{*}{ Governor's party } & \multicolumn{2}{|c|}{ Ordered Logit } & \multicolumn{2}{|c|}{ OLS } \\
\hline & Democrat & Republican & Democrat & Republican \\
\hline State unemployment rate & $\begin{array}{l}-0.11 \\
(0.14)\end{array}$ & $\begin{array}{l}-0.38^{*} \\
(0.17)\end{array}$ & $\begin{array}{l}-0.05 \\
(0.05)\end{array}$ & $\begin{array}{l}-0.18^{*} \\
(0.07)\end{array}$ \\
\hline * Republican respondent & $\begin{array}{l}-0.39^{*} \\
(0.17)\end{array}$ & $\begin{array}{l}-0.26 \\
(0.23)\end{array}$ & $\begin{array}{l}-0.18^{*} \\
(0.07)\end{array}$ & $\begin{array}{l}-0.11 \\
(0.09)\end{array}$ \\
\hline Bush approver & $\begin{array}{l}-1.02 * \\
(0.23)\end{array}$ & $\begin{array}{l}1.96^{*} \\
(0.16)\end{array}$ & $\begin{array}{l}-0.46^{*} \\
(0.09)\end{array}$ & $\begin{array}{l}0.98 * \\
(0.07)\end{array}$ \\
\hline * Republican respondent & $\begin{array}{l}-0.08 \\
(0.20)\end{array}$ & $\begin{array}{l}-0.55^{*} \\
(0.14)\end{array}$ & $\begin{array}{l}-0.07 \\
(0.09)\end{array}$ & $\begin{array}{l}-0.31^{*} \\
(0.07)\end{array}$ \\
\hline Republican respondent & $\begin{array}{l}0.12 \\
(0.76)\end{array}$ & $\begin{array}{l}2.51^{*} \\
(1.04)\end{array}$ & $\begin{array}{l}0.04 \\
(0.30)\end{array}$ & $\begin{array}{l}1.16^{*} \\
(0.39)\end{array}$ \\
\hline Demographic controls & Yes & Yes & Yes & Yes \\
\hline Cut 1 or Constant & $\begin{array}{l}-3.49^{*} \\
(0.73)\end{array}$ & $\begin{array}{l}-1.92^{*} \\
(0.80)\end{array}$ & $\begin{array}{l}3.32 * \\
(0.27)\end{array}$ & $\begin{array}{l}2.60^{*} \\
(0.35)\end{array}$ \\
\hline Cut 2 & $\begin{array}{l}-2.17 * \\
(0.72)\end{array}$ & $\begin{array}{l}-0.54 \\
(0.82)\end{array}$ & & \\
\hline Cut 3 & $\begin{array}{l}0.07 \\
(0.72)\end{array}$ & $\begin{array}{l}1.49^{\dagger} \\
(0.85)\end{array}$ & & \\
\hline $\mathrm{N}$ & 6495 & 9986 & 6495 & 9986 \\
\hline Clusters (states) & 21 & 28 & 21 & 28 \\
\hline $\mathrm{R}^{2}$ & - & - & 0.38 & 0.37 \\
\hline
\end{tabular}


Table 6: Gubernatorial Approval and the State Economy (SurveyUSA)

\begin{tabular}{lllll}
\hline \hline & \multicolumn{3}{c}{ Democratic governor } & \multicolumn{2}{c}{ Republican governor } \\
\hline \hline Respondent party & Republican & Democrat & Republican & Democrat \\
& & & & \\
State unemployment & $-13.99^{*}$ & -4.56 & $-6.43^{*}$ & $-7.40^{*}$ \\
& $(4.04)$ & $(2.91)$ & $(1.92)$ & $(2.34)$ \\
Bush approval level & $1.70^{*}$ & $0.92^{\dagger}$ & 0.52 & 0.48 \\
& $(0.69)$ & $(0.46)$ & $(0.45)$ & $(0.75)$ \\
Constant & -26.30 & $79.97 *$ & 59.95 & $70.24^{*}$ \\
& $(59.63)$ & $(16.46)$ & $(36.59)$ & $(14.99)$ \\
& & & & \\
$\mathrm{N}$ & 19 & 19 & 28 & 28 \\
$\mathrm{R}^{2}$ (adjusted) & $0.57(0.51)$ & $0.42(0.35)$ & $0.33(0.28)$ & $0.30(0.24)$ \\
& & & & \\
Note: Standard errors in parentheses. The dependent variable is the aggregate approval level among the specified \\
group of respondents. ${ }^{\dagger} \mathrm{p} \leq 0.10,{ }^{*} \mathrm{p} \leq 0.05$.
\end{tabular}




\section{Table 7: Marginal Effects of State Economic Evaluations on Gubernatorial Voting}

\begin{tabular}{|c|c|c|c|}
\hline & $\begin{array}{l}\text { All respondents (from } \\
\text { Carsey and Wright) }\end{array}$ & $\begin{array}{l}\text { Republican } \\
\text { respondents only }\end{array}$ & $\begin{array}{l}\text { Democratic } \\
\text { respondents only }\end{array}$ \\
\hline Democratic governor 1986 & $\begin{array}{l}0.59^{*} \\
(0.14)\end{array}$ & $\begin{array}{l}0.60^{*} \\
(0.18)\end{array}$ & $\begin{array}{l}0.16 \\
(0.19)\end{array}$ \\
\hline Republican governor 1986 & $\begin{array}{l}0.66^{*} \\
(0.09)\end{array}$ & $\begin{array}{l}0.86^{*} \\
(0.39)\end{array}$ & $\begin{array}{l}0.67 * \\
(0.21)\end{array}$ \\
\hline \multicolumn{4}{|c|}{$\begin{array}{l}\text { Note: Coding follows Carsey and Wright (1998), except the dependent variable is a dummy coded } 1 \text { if the } \\
\text { respondent reported voting for the incumbent gubernatorial candidate. Figures shown are coefficients for the } \\
\text { marginal effect of respondent evaluations of the state economy from six separate logistic regressions, with } \\
\text { standard errors in parentheses. These economic evaluations range over a four-point scale, with higher scores } \\
\text { indicating better evaluations. Data source is the } 1986 \text { CBS/New York Times exit poll, obtained from ICPSR. Other } \\
\text { variables not shown are the same as in Carsey and Wright (1998). *p } \leq 0.05 \text {. }\end{array}$} \\
\hline
\end{tabular}

